\begin{abstract}
Представлено структуру ексергетичного балансу тіла людини для зимового та літнъого періодів. Отримано залежність споживання ексергї̈ людським тілом від середнъої радіаційної температури та температури повітря в кімнаті для зимового періоду. Проаналізовано різні моделі теплового комфорту людини та розроблено комплексну модель на базі енергетичного та ексергетичного підходів для аналізу складної системи джерело тепла - людина - огороджувальні конструкції. За допомогою моделі визначено мінімальне споживання ексераї людським тілом, структура ексергетичного балансу та температурні умови комфортності
\end{abstract}

Ключові слова: тепловий комфорт, енергоефективність, будівля, ексергія, споживання ексергії людським тілом

口-

Представлена структура эксергетического баланса тела человека для зимнего и летнего периодов. Получена зависимость потребления эксергии человеческим телом средней радиачионной температуры и температуры воздуха в комнате для зимнего периода. Проанализированы различные модели теплового комфорта человека и разработана комплексная модель на базе енергетического $u$ ексергетического подходов для анализа сложной системь источник тепла - человек - ограждающие конструкции. С помощью модели определены минимальное потребление эксергии человеческим телом, структура эксергетического баланса и температурные условия комфортности

Ключевые слова: тепловой комфорт, энергоэффективность, здание, эксергия, потребление эксергии человеческим телом

\title{
A MODEL OF HUMAN THERMAL COMFORT FOR ANALYSING THE ENERGY PERFORMANCE OF BUILDINGS
}

\author{
V. Desh ko \\ Doctor of technical sciences, \\ Professor, Head of Department* \\ E-mail: te@kpi.ua \\ N. B u y a k \\ Postgraduate student* \\ E-mail: korovaj.te@gmail.com \\ *Department of Heat Engineering \\ and Energy Saving \\ National Technical University of Ukraine \\ "Kyiv Polytechnic Institute" \\ Peremohy ave., 37, Kyiv, Ukraine, 03056
}

1. Introduction

At present, an efficient use of heat energy of houses is a vital issue. Thermal comfort in the room is no less important under growing demands of energy conservation. A compromise between these two requirements without harm to human health is the main challenge of energy efficiency experts.

Mathematical models of human thermal sensation under various ambient parameters are necessary to design heating systems and control their operation. In addition, providing comfortable conditions is a limiting factor under the growing requirements of energy conservation. There exists a great variety of human thermopsychological models; their design and development began in 1970 [1]. The main and wellknown are two models of human thermal sensation [2,3]. Model [2] is a two-node human energy model that covers thermal sensation under transient environmental conditions. The international standard for determining thermal comfort is based on empirical model [3], which allows taking into account the intensity of human activity, type of clothing, air velocity, relative humidity, room air temperature $t_{a}$, and mean radiant temperature $t_{r}$. Model [4] determines a winter relationship between $t_{a}$ and $t_{r}$ based on the intensity of human activity. Modern scholars consider a human being as a complex system consisting of 18 nodes [1] and create a neural model for controlling blood flow to the skin in order to provide and improve the human thermal comfort. An exergic approach consists in determining the minimum human body exergy consumption and is based on the energy model, which allows taking into account environmental and human factors. In addition, this model determines the minimum exergy destruction in the two-node human system and the necessary conditions for this minimum. Consideration of comfortable conditions in energy and exergy analyses of the energy performance of buildings is an important and insufficiently studied factor.

\section{Analysis of the previous studies and formulation of the problem}

Basic principles of viewing a building as a unified energy system are presented in [5]. It is suggested that in Ukraine design of energy efficient buildings should also be considered as optimization of interconnected balanced subsystems [6]. It is proposed that the selection of energy efficient means for the existing buildings should be based on devised algorithms. There are linear model based approaches [7] to the choice of investment projects that are aimed at reducing energy consumption of buildings; there also exist approaches based on the nonlinear energy function of marginal utility [8] and the fuzzy set theory [9]. At different stages of the building life cycle, researchers use complex approaches to its energy efficiency based on the heat source and the building envelope. An exergy approach that allows qualitative assessment of energy flows from various heat sources is a new tool in the comprehensive analysis. Qualitative assessment of energy flows in a complex building system is made in 
$[10,11]$. This analysis pointed out segments of the system where exergy destruction is the highest. The combination of exergy analysis of the entire building and exergy analysis of the human body [12] allows reducing exergy consumption of the system and providing the building microclimate that would correspond to the highest human efficiency in terms of the second law of thermodynamics.

In the analysis and design of complex systems such as "heat source - building", there remains a problem of including a human being and mathematical models of thermal comfort in the design and construction of buildings with a high-quality microclimate that is provided by the systems of heating, ventilation and air-conditioning. A model of human thermal comfort was not taken into account in the earlier consideration of a building as a complex energy system [13]. Later on authors considered the effect of favorable conditions on the integrated cost of the system "heat source - building envelope" [14], although they viewed Bogoslovsky's model (that indicates a general range of conditions, is less complicated, and depends only on the intensity of human activity) as a model of thermal comfort. Therefore, the growing demands of the buiding thermal comfort and an integrated approach to the choice of energy-saving measures and to the entire building generally require the use of thermal comfort models that take into account the intensity of human activity, the type of clothing, air velocity in the room, and relative humidity. Depending on the purpose of research, scientists present various thermal comfort models that are based on energy [15] and exergy balances [16, 17]. The authors of [18] made a nonstationary analysis of the human body exergy balance on the basis of the stationary model for summer conditions. Analysis of the effect of thermal protection of the building envelope on exergy consumption of the human body [17] in different climatic conditions showed that exergy consumption decreases by $0.6 \%, 6.4 \%, 10.1 \%$, and $35.9 \%$ for warm/humid, temperate, warm/dry and cold climate types, respectively, whereas thermal protection improves. The structures of energy and exergy balances of the human body in summer are reflected in [18]. It is found that the minimum human body exergy consumption corresponds to the human thermal sensation "slightly cool" [19], provided that exergy counting starts from the room air temperature. Therefore, a promising method consists in an integrated approach to the system "heat source - human being - building envelope" since it provides a combination of comfort and energy efficiency of the building. An integrated approach requires an appropriate model to determine whether thermal comfort and energy performance of the system are provided at required levels. Meantime, exergy analysis is widely used under multivariant energy transformations.

\section{The purpose and objectives of the study}

The study is aimed at developing a comprehensive energy and exergy thermal comfort model for analysing the system "heat source - human being - building envelope". To achieve the goal we set the following tasks:

- to develop a thermal comfort model taking into account the peculiarities of its use as a component of the system "heat source - human being - building envelope";

- to use the thermal comfort model in determining the dependence of the human body exergy consumption on the room air temperature at different values of the mean radiant temperature in winter, as well as the minimum value of exergy consumption and the respective Predicted Mean Vote (PMV) of thermal sensation;

- to compare the dependence of the room air temperature on the mean radiant temperature for different models of thermal comfort.

\section{Models of human thermal comfort}

The basic model of evaluating the thermal sensation of a human being [3] that is embodied in European standards takes into account the intensity of human labor, the type of clothing, and air relative humidity. V. N. Bogoslovsky suggested a simpler correlation between the mean radiant temperature and room air temperature (corresponding to comfortable conditions in cold season) that depends on the intensity of human activity [4]. This model was used by the authors who determined the impact of favorable conditions in the building on heating characteristics and on the choice of heat sources and the thermal protection of buildings [13].

The human body exergy balance model (examined in [16-21]) is based on the two-node human energy model [2] that takes into account the heat loss through respiration, moisture evaporation, convection, and radiation. Thermoregulation of the human body is maintained by the varying blood circulation velocity that results from the expansion and constriction of blood vessels.

The design and study of functioning conditions of the complex system "heat source - human being - building envelope" require application of a model with regard to factors that depend on human beings, their clothes, activities, and environment as well as ensure the desired level of comfort by means of the Predicted Mean Vote (PMV) index. This requires supplementing the system model described in [13] with an embedded mathematical model of human comfort; hereby, comfort assessment depends on the above factors, and the model is linked to the building energy balance with the heat gain, $t_{a}$, and $t_{r}$.

The models of human energy [22] and human body exergy balance [17] laid the basis for creating a mathematical model of a human being that allows specifying the structure of exergy balance, human body exergy consumption, its minimum value, and air temperature that corresponds to it. The value of comfortable room air temperature under the exergy approach allows comparing it with the energy approach as well as project a heat source and determine the system energy performance so as to ensure the minimum or specified human body exergy consumption. This model is stationary, with no regard to the energy and exergy accumulated in the human body core and skin. The admissibility of such assumptions in terms of the impact on the structure of energy balance is analysed in Section 4.2.

\section{1. Devising a model of human thermal comfort}

Provided that the ambient temperature is constant, the energy balance of the human body that has skin-core morphology is represented by the following equations [21]:

$$
\begin{aligned}
& \mathrm{S}_{\mathrm{sk}}=\mathrm{K}_{\min } \cdot\left(\mathrm{T}_{\mathrm{cr}}-\mathrm{T}_{\mathrm{sk}}\right)+\mathrm{c}_{\mathrm{bl}} \cdot \mathrm{V}_{\mathrm{bl}} \cdot\left(\mathrm{T}_{\mathrm{cr}}-\mathrm{T}_{\mathrm{sk}}\right)-\mathrm{E}_{\mathrm{sk}}-\mathrm{DRY}, \\
& \mathrm{S}_{\mathrm{cr}}=\left(\mathrm{M}-\mathrm{E}_{\mathrm{res}}-\mathrm{W}\right)-\mathrm{K}_{\mathrm{min}} \cdot\left(\mathrm{T}_{\mathrm{cr}}-\mathrm{T}_{\mathrm{sk}}\right)-\mathrm{c}_{\mathrm{bl}} \cdot \mathrm{V}_{\mathrm{bl}} \cdot\left(\mathrm{T}_{\mathrm{cr}}-\mathrm{T}_{\mathrm{sk}}\right),
\end{aligned}
$$

where $\mathrm{S}_{\mathrm{cr}}$ and $\mathrm{S}_{\text {sk }}$ denote the energy stored in the core and skin, $\mathrm{W} / \mathrm{m}^{2} ; \mathrm{K}_{\min }$ is an effective thermal conductivity between the human core and skin $=5.28 \mathrm{~W} / \mathrm{m}^{2} \mathrm{~K}$; $\mathrm{T}_{\text {cr }}$ is the 
core temperature, $\mathrm{K} ; \mathrm{T}_{\mathrm{sk}}$ is the skin temperature, $\mathrm{K} ; \mathrm{c}_{\mathrm{bl}}$ is the specific heat of human blood $=1.163 \mathrm{~W} \cdot \mathrm{h} / 1 \cdot{ }^{\circ} \mathrm{C} ; \mathrm{V}_{\mathrm{bl}}$ is blood flow to the skin, $\mathrm{kg} / \mathrm{s} \cdot \mathrm{m}^{2}$.

The magnitude $\mathrm{DRY}=(\mathrm{R}+\mathrm{C})$ is known as dry heat transfer from the body surface and determined as follows:

$$
\mathrm{DRY}=\mathrm{h} \cdot \mathrm{F}_{\text {cle }} \cdot\left(\mathrm{T}_{\mathrm{sk}}-\mathrm{T}_{\mathrm{a}}\right)
$$

where $\mathrm{h}$ is a combined heat transfer coefficient, $\mathrm{W} / \mathrm{m}^{2} \cdot{ }^{\circ} \mathrm{C}$; $F_{\text {cle }}$ is the clothing thermal efficiency factor; $T_{a}$ is room air temperature, $\mathrm{K}$.

Heat losses through evaporation can be of three types:

$\mathrm{E}_{\mathrm{res}}$ is the heat from liquid evaporation due to respiration; $E_{s k}$ is the heat from the skin surface evaporation; $E_{\text {diff }}$ is the heat from evaporation of the liquid that diffuses from the skin; $\mathrm{E}_{\text {reg.sw }}$ is the heat from sweating while regulating the body temperature.

$$
\begin{aligned}
& \mathrm{E}_{\mathrm{sk}}=\mathrm{w} \cdot \mathrm{E}_{\mathrm{max}}, \\
& \mathrm{E}_{\mathrm{sk}}=\left(0.06+0.094 \cdot \mathrm{w}_{\text {reg.sw }}\right) \cdot \mathrm{E}_{\text {max }}, \\
& \mathrm{w}_{\text {reg.sw }}=\frac{\mathrm{E}_{\text {reg.sw }}}{\mathrm{E}_{\text {max }}}, \\
& \mathrm{E}_{\text {reg.sw }}=0.7 \cdot \mathrm{m}_{\text {reg.sw }} \cdot 2^{\frac{\mathrm{t}_{\text {sk }}-34.1}{3}},
\end{aligned}
$$

where $\mathrm{E}_{\max }$ is the maximum possible evaporation from the skin surface, $\mathrm{W} / \mathrm{m}^{2}$; $\mathrm{w}$ is the skin wetness index; $\mathrm{w}_{\text {reg.sw }}$ is skin wetness caused by regular sweating; 0.7 is the latent heat of sweat, $\mathrm{W} \cdot \mathrm{h} / \mathrm{g} ; \mathrm{m}_{\text {reg.sw }}$ is a measure of the regular sweat cover on the skin, $\mathrm{g} / \mathrm{h} \cdot \mathrm{m}^{2}$.

$$
\mathrm{E}_{\max }=\mathrm{k} \cdot \mathrm{h}_{\mathrm{c}} \cdot\left(\mathrm{p}_{\mathrm{sk}}-\mathrm{p}_{\mathrm{a}}\right) \cdot \mathrm{F}_{\mathrm{pcl}},
$$

where $\mathrm{k}$ is the Lewis number $=2.2{ }^{\circ} \mathrm{C} / \mathrm{mm} \mathrm{Hg}$; $\mathrm{p}_{\text {sk }}$ is the saturated vapour pressure for the temperature $\mathrm{T}_{\mathrm{sk}}, \mathrm{mm} \mathrm{Hg} ; \mathrm{F}_{\mathrm{pcl}}$ is the vapour permeation efficiency factor that depends on the convective heat transfer and the clothing thermal insulation.

Thermoregulation system, namely temperature signals from the skin and the core, is described by means of the following equations:

$$
\begin{aligned}
& \sum_{\mathrm{sk}}=\mathrm{t}_{\mathrm{sk}}-34.1, \\
& \sum_{\mathrm{cr}}=\mathrm{t}_{\mathrm{cr}}-36.6,
\end{aligned}
$$

where $\Sigma_{\text {cr }}$ and $\Sigma_{\text {sk }}$ denote temperature signals from the core and the skin, respectively, ${ }^{\circ} \mathrm{C}$.

The mass of sweat and the velocity of blood circulation through vessels, respectively, are determined on the basis of these two signals [21]:

$$
\begin{aligned}
& \mathrm{m}_{\text {reg.sw }}=\left\{\begin{array}{l}
0, \text { if } \sum_{\mathrm{cr}}<0 \cup \sum_{\mathrm{sk}}<0, \\
250+100 \cdot \sum_{\mathrm{cr}},
\end{array}\right. \\
& \mathrm{V}_{\mathrm{bl}}=\left\{\begin{array}{l}
\frac{6.3+75 \cdot \sum_{\mathrm{cr}}}{1-0,5 \cdot \sum_{\mathrm{sk}}}, \text { if } \sum_{\mathrm{cr}}>0 \cup \cap \sum_{\mathrm{sk}}<0, \\
6.3 \text { otherwise. }
\end{array}\right.
\end{aligned}
$$

Equations (1)-(12) of the specified ambient parameters are used to calculate $\mathrm{T}_{\mathrm{cr}}, \mathrm{T}_{\mathrm{sk}}$, and $\mathrm{E}_{\mathrm{sk}}$. These indices allow calcu- lating the human body exergy consumption on the basis of exergy balance.

The human body exergy balance is found as follows [14]:

$$
\begin{aligned}
& \mathrm{Ex}_{\mathrm{m}}+\mathrm{Ex}_{\mathrm{gen.cr}}+\mathrm{Ex}_{\text {gen.sk }}+\mathrm{Ex}_{\mathrm{inh} . \mathrm{air}}+ \\
& +\mathrm{Ex}_{\text {abs.sk-cl }}=\mathrm{Ex}_{\text {rad.dc }}+\mathrm{Ex}_{\text {conv }}+\mathrm{Ex}_{\text {exh.air }}+ \\
& +\mathrm{Ex}_{\text {sw.ha }}+\mathrm{Ex}_{\text {stored.cr }}+\mathrm{Ex}_{\text {stored.sk }}+\mathrm{Ex}_{\text {cons }},
\end{aligned}
$$

where $E x_{m}$ is the heat exergy determined by the metabolic rate; $\mathrm{Ex}_{\mathrm{gen} . c \mathrm{cr}}$ is the exergy of liquid generated in the core due to metabolic processes; Ex $x_{\text {gen.sk }}$ is the exergy of liquid generated in the skin due to metabolic processes; $\mathrm{Ex}_{\text {inh.air }}$ is the exergy of humid air that a person inhales; $\mathrm{Ex}_{\mathrm{abs.sk}-\mathrm{cl}}$ is the exergy of radiation absorbed by human skin and clothing; $\mathrm{Ex}_{\mathrm{rad} . \mathrm{dc}}$ is the exergy of radiation discharged from the body surface; $\mathrm{Ex}_{\mathrm{conv}}$ is the exergy transmitted to air by convection; $\mathrm{Ex}_{\mathrm{exh} \text {,air }}$ is the exergy of humid air that a person exhales; $\mathrm{Ex}_{\mathrm{sw}, \mathrm{ha}}$ is the exergy of vapour that results from sweating; $\mathrm{Ex}_{\text {stored.cr }}$ is the exergy stored in the core; $\mathrm{Ex}_{\text {stored. sk }}$ is the exergy stored in the skin; Ex $_{\text {cons }}$ is the exergy consumed by the human body.

Empirical equations (1)-(13) laid the basis for mathematical modelling of the human being in Mathcad. This model allows determining the minimum human body exergy consumption, the air temperature that corresponds to it, and the Predicted Mean Vote (PMV) index of the human being in accordance with the International Standard EN ISO 7730. The research model input parameters are shown in Table 1. They are needed to compare the structures of the human body exergy balance in winter and in summer. The model efficiency is assessed by comparing the calculated values of the human body exergy balance with the results of [16].

Table 1

The research system specifications

\begin{tabular}{|l|c|c|}
\hline \multicolumn{1}{|c|}{ Parameter } & \multicolumn{2}{c|}{ Value } \\
\hline \multicolumn{1}{|c|}{ Environment } & summer & winter \\
\hline Ambient air temperature $\mathrm{T}_{0}, \mathrm{~K}$ & 301 & 273 \\
\hline Ambient relative humidity $\phi_{0}, \%$ & \multicolumn{2}{|c|}{40} \\
\hline Relative humidity in the room $\phi_{\mathrm{v}}, \%$ & \multicolumn{2}{|c|}{40} \\
\hline Atmospheric pressure, $\mathrm{Pa}$ & \multicolumn{2}{|c|}{101325} \\
\hline \multicolumn{2}{|c|}{ Human } \\
\hline Clothing thermal insulation, $\mathrm{m}^{2 .}{ }^{\circ} \mathrm{C} / \mathrm{W}$ & 0.124 & 0.155 \\
\hline Metabolic rate, $\mathrm{W} / \mathrm{m}^{2}$ & \multicolumn{2}{|c|}{58} \\
\hline Mechanical work, $\mathrm{W} / \mathrm{m}^{2}$ & \multicolumn{2}{|c|}{0} \\
\hline
\end{tabular}

\section{2. The modelling results}

Fig. 1, $a$ presents the share of incoming exergy flows, and Fig. 1, $b$ - outgoing flows described in [16] under the following conditions: $\mathrm{t}_{\mathrm{a}}=\mathrm{t}_{\mathrm{r}}=24^{\circ} \mathrm{C}, \mathrm{t}_{0}=28{ }^{\circ} \mathrm{C}$, relative humidity $=40 \%$, human activity $=58 \mathrm{~W} / \mathrm{m}^{2}$, the thermal resistance of clothing $=0.124 \mathrm{~m}^{2}{ }^{\circ} \mathrm{C} / \mathrm{W}$ (corresponding to $0.8 \mathrm{clo}$ ), and air velocity $=0.15 \mathrm{~m} / \mathrm{s}$. Obviously, the accumulation of exergy in the core and the skin is small -0.006 and $0.009 \%$, respectively, thus, it is waived in the calculations.

Fig. 2, $a, b$ present shares of incoming and outgoing exergy flows for the designed stationary model of a human being without taking into account exergy and energy accumulation in the core and the skin in conditions similar to those of [16]. The balance of incoming flows obtained with the help of the devised model is similar to the example presented by 
the author of [16], Fig. 1. The balance of the incoming exergy flows is different: for instance, exergy consumed by the human body and exergy of the exhaled air differ by $4 \%$ from model [16]. The error of results is on average $4 \%$. So this model should be applied in future research.

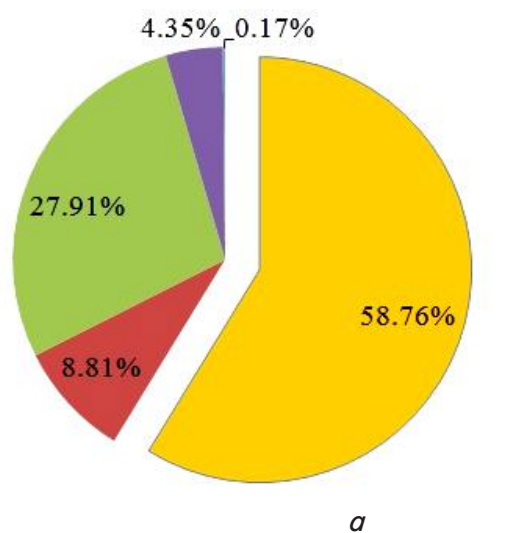

$\square \operatorname{Exm}$

Exgencr

Exgensk

Exabsskcl

Exinhair

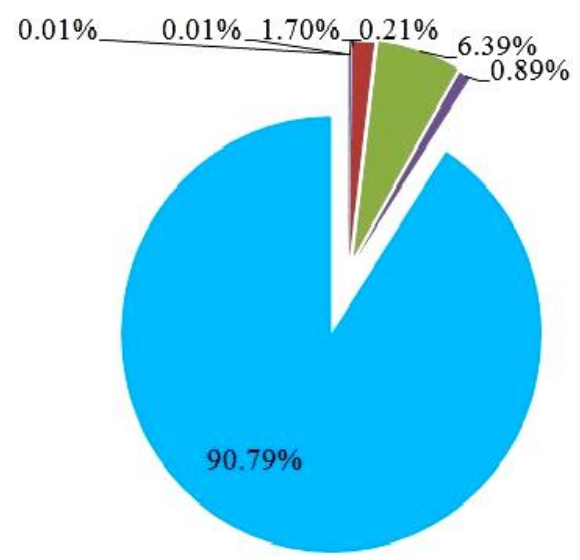

- Exraddc

Exconv

Exexhair

Exswha

Excons

Exstored,cr

Exstored,sk$$
\text { b }
$$

Fig. 1. The structure of the human body exergy balance [16]

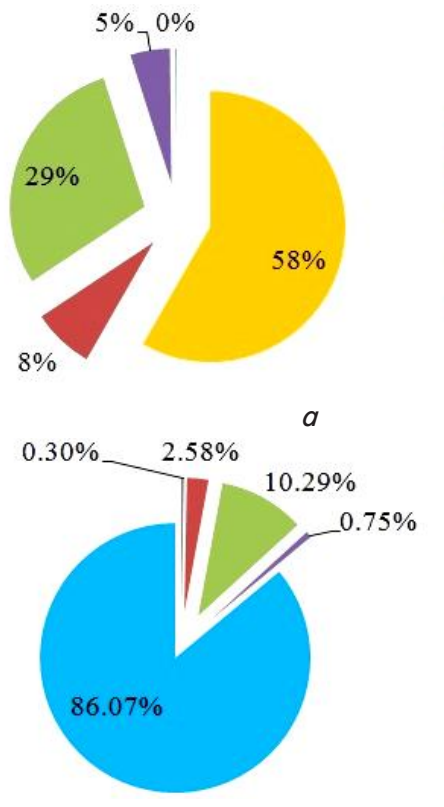

b
Exm

Exgencr

Exgenmbda

Exabsskcl

Exraddc

Exconv

Exexhair

- Exswha

Excons
Exinhair

Fig. 2. The structure of the human body exergy balance in warm season: $a$ - the incoming exergy flow; $b-$ the outgoing exergy flow
Fig. 3 shows the human body exergy balance in winter. The respective parameters of the model are presented in Table 1: $\mathrm{t}_{\mathrm{a}}=\mathrm{t}_{\mathrm{r}}=20{ }^{\circ} \mathrm{C}, \mathrm{t}_{0}=0{ }^{\circ} \mathrm{C}$, relative humidity $=40 \%$, human activity $=58 \mathrm{~W} / \mathrm{m}^{2}$, the thermal resistance of clothing $=0.155 \mathrm{~m}^{2}{ }^{\circ} \mathrm{C} / \mathrm{W}$ (corresponding to $1 \mathrm{clo}$ ), and air velocity $=0.15 \mathrm{~m} / \mathrm{s}$. The structures of outgoing exergy flows change with varying environmental conditions and parameters of the room microclimate. If in summer the bulk of the outgoing exergy flow corresponds to the human body exergy consumption $-86 \%$, in winter it is the exergy of radiation - $53 \%$, whereas the human body exergy consumption makes up only $16 \%$, which is explained by a more significant difference between the skin surface temperature and the ambient temperature. The room temperature considered in the study is 24 and $20{ }^{\circ} \mathrm{C}$ for summer and winter conditions, respectively, and an increase in the absolute value of the convection and radiation heat transfer in the balance results in a reduced share of the human body exergy consumption.

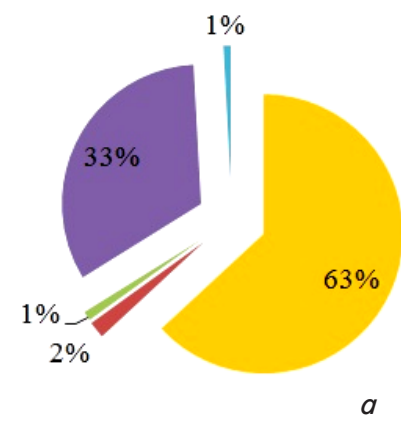

Exm

Exgencr

Exgensk

Exabsskcl

Exinhair
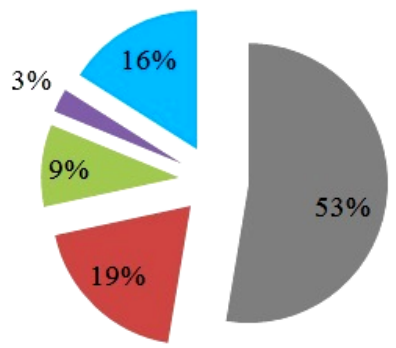

Exraddc

Exconv

Exexhair

Exswha

Excons

$b$

Fig. 3. The structure of the human body exergy balance in cold season: $a$ - the incoming exergy flow; $b$ - the outgoing exergy flow

Fig. 4, 5 show the dependence of exergy consumption on the mean radiant temperature and room air temperature for the system specifications presented in Table 1. The humn body exergy consumption varies according to the microclimate in the room and parameters of a person. Fig. 4 shows how changes in the human body exergy consumption depend on the room temperature. Different diagrams correspond to different values of the mean radiant temperature in the room, whereas other parameters remain unchanged. When $t_{a}$ is low, exergy consumption increases due to shivering of the human body, and if the room temperature increases, $\mathrm{E}_{\text {cons }}$ reaches its minimum and increases due to cooling of the skin surface, which results from moisture evaporation.

In graph 4, the values of PMV and PPD are calculated for the points that correspond to the minimum exergy consumption. PPD is the Predicted Percentage of Dissatisfied with the environment, the main parameters of the 
human thermal sensation meet the International Standard EN ISO 7730. The PMV value is between -0.34 and -0.42 . In [16], the minimum exergy consumption corresponds to $\mathrm{PMV}=-0.611$ (although the ambient temperature was considered as equal to the room temperature).

Fig. 5 shows a surface that reflects the dependence of the human body exergy consumption on $t_{\mathrm{a}}$ and $t_{\mathrm{r}}$ if $t_{\mathrm{a}}$ varies in the range of $15-30{ }^{\circ} \mathrm{C}$ and $\mathrm{t}_{\mathrm{r}}-15-30{ }^{\circ} \mathrm{C}$.

The compared dependences $t_{a}\left(t_{r}\right)$ of different thermal comfort models are shown in Fig. 6.

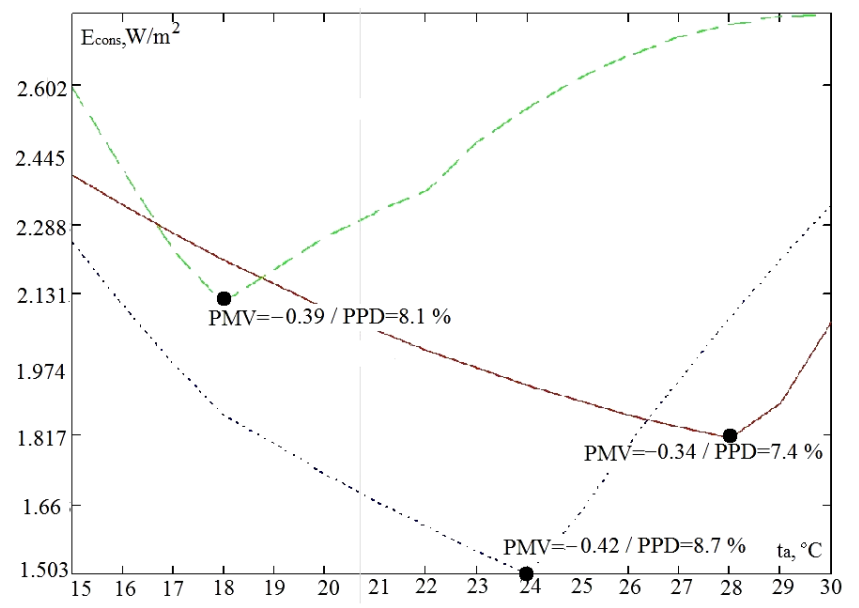

Fig. 4. The graphs of dependence of the human body exergy consumption $E_{\text {cons }}$ on the room temperature $t_{a}$ for various values of the mean radiant temperature $t_{r}$ : - - for $\mathrm{t}_{\mathrm{r}}=15^{\circ} \mathrm{C} ; \ldots-\mathrm{for}_{\mathrm{r}}=20^{\circ} \mathrm{C}$; - - for $\mathrm{t}_{\mathrm{r}}=28^{\circ} \mathrm{C}$; - - the minimum exergy consumption

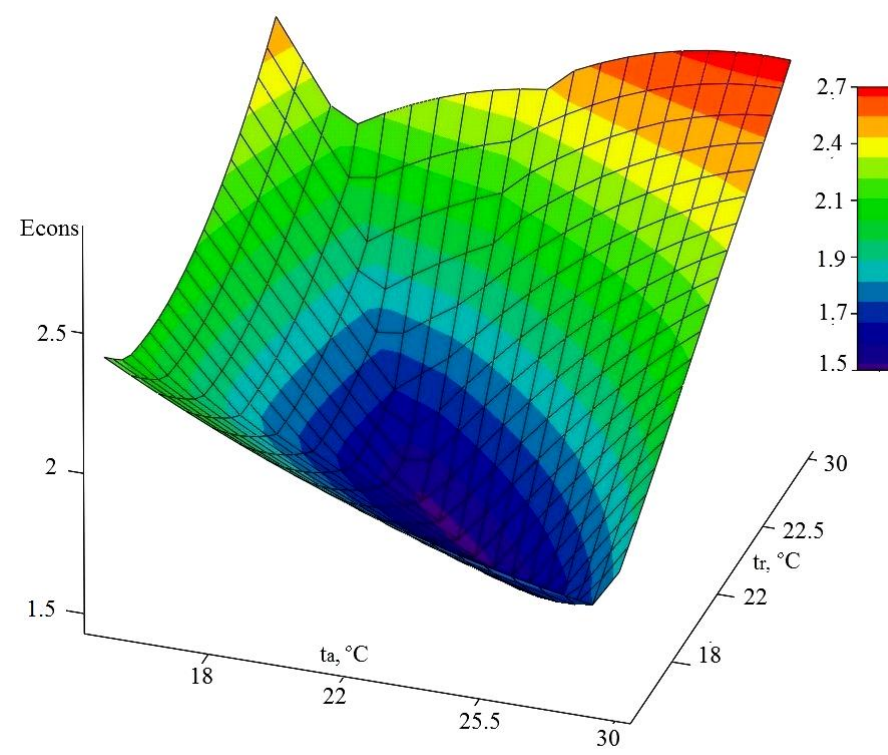

Fig. 5. The surface of the human body exergy consumption $E_{\text {cons }}$ that depends on the room air temperature $t_{a}$ and the mean radiant temperature $t_{r}$

When $t_{r}$ values vary, the difference of comfortable indoor air temperature under the exergy approach and at $\mathrm{PMV}=0$ lies in the range of $0.8-1.4{ }^{\circ} \mathrm{C}$. In order to compare the results of various thermal comfort models, we calculated the standard deviation of the comfortable room air temperature compared to a comfortable temperature at which the predicted human thermal sensation would correspond to $\mathrm{PMV}=0$ (the thermal sensation is "comfortable"). The energy model of the human body with $\mathrm{PMV}=0$ is chosen as the basic one since it is the most common and is the basis of the International Standard EN ISO 7730. The highest standard deviations of the comfortable air temperature are typical of the model with PMV=1 and -1 and make up 7.3 and $7.2{ }^{\circ} \mathrm{C}$, respectively. The standard deviations for Bogoslovsky's model are 5.1 and $5.7^{\circ} \mathrm{C}$, respectively; for the model with $\mathrm{PMV}=-0.5$ and $0.5-3.7$ and $3.8^{\circ} \mathrm{C}$, respectively. The lowest value of the standard deviation corresponds to the exergy model of thermal comfort and is equal to $1.4^{\circ} \mathrm{C}$.

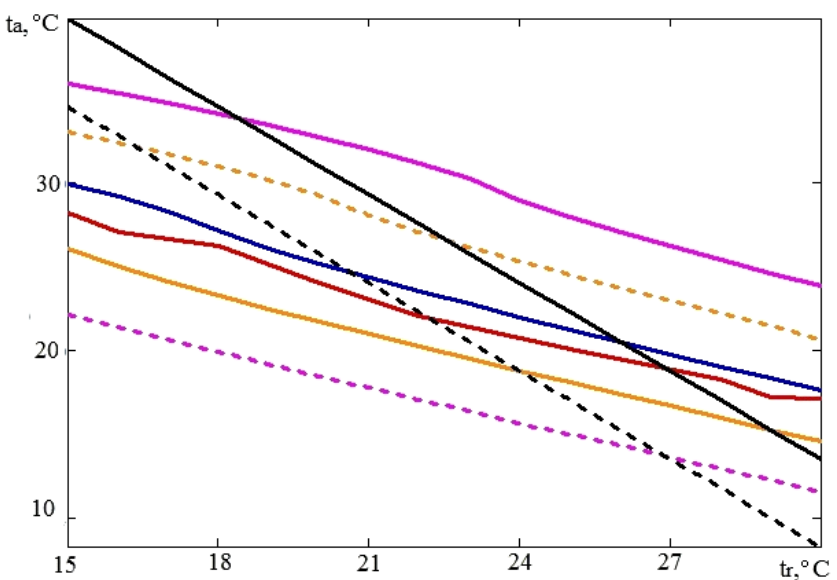

Fig. 6. The graphs of dependence of the mean radiant air temperature $t_{r}$ on the room air temperature $t_{a}$ for various models of thermal comfort: -- the minimum exergy consumption; $-\mathrm{PMV}=0 ;=-\mathrm{PMV}=0.5$;

$$
\begin{gathered}
-\mathrm{PMV}=-0.5 ; \quad-\mathrm{PMV}=1 ;=-+-\mathrm{PMV}=-1 ; \\
\text { Bogoslovsky }[15]
\end{gathered}
$$

\section{Discussion of the results and comparison of various human comfort models}

In summer, convective and radiative heat transfer from the human body surface is low compared to other components, which results from the small difference between the skin temperature and room air temperature. Thereby, the share of the human body exergy consumption grows in the total balance in comparison with winter conditions.

From a scientific point of view, the minimum exergy consumption is more reasonable than the PMV index of the human thermal sensation calculated according to EN ISO 7730. The studies have shown that the minimum exergy consumption corresponds to PMV between -0.34 and -0.42 (the thermal sensation is "slightly cool") if the ambient temperature is $0{ }^{\circ} \mathrm{C}$, which corresponds to winter conditions (other researchers performed simulations based on the assumption that the room air temperature is equal to the ambient temperature). If $\mathrm{t}_{\mathrm{o}}=\mathrm{t}_{\mathrm{a}}=20^{\circ} \mathrm{C}$, the minimum exergy consumption corresponds to $\mathrm{PMV}=-0.611$ [17].

The conditions of study and comparison of different comfort models fit the parameters given in Table 1 (winter). Bogoslovsky's model is the simplest one and is represented by an appropriate range of $t_{a}\left(t_{r}\right)$. It is recommended for the rooms with heating systems that considerably increase the radiant temperature. Fig. 6 shows that if the mean ra- 
diant temperature $=27^{\circ} \mathrm{C}$, the upper limit of comfortable temperature range corresponds to $\mathrm{PMV}$ that is close to neutral conditions, and the botoom limit of $P M V=-1$ (the thermal sensation is "cold"). If the accepted mean radiant temperature $=18^{\circ} \mathrm{C}$, the upper limit of comfortable temperature corresponds to $\mathrm{PMV}=1$, and the bottom one is close to comfortable conditions. Thus, if the mean radiant temperature is high, it is recommended to select the highest value of temperature range in Bogoslovsky's model, and if it is low - the lowest. However, if modern computer technologies are used in the design and study of the complex system "heat source - human being - building envelope”, Fanger's model should be applied because it allows taking into account factors that depend on the human and the environment, as well as ensuring the desired level of comfort by means of the Predicted Mean Vote index.

The difference between the designed model and model [3] is that the Predicted Mean Vote index of human thermal sensation is based on an empirical model, and the basis for determining the minimum exergy consumption is an approach based on the second law of thermodynamics that consists in minimizing exergy destruction.

Comparison of the standard deviation of comfortable temperature from the base for various models of human thermal comfort has shown that the lowest value of the standard deviation corresponds to the exergy model of thermal comfort and equals to $1.4^{\circ} \mathrm{C}$. So we can assume that providing comfort under the exergy approach allows lowering the room air temperature on average by $1.4{ }^{\circ} \mathrm{C}$ and, thus, saving energy.

\section{Conclusions}

1. The stationary model of human thermal comfort is designed with account of the peculiaritis of its use as part of the system "heat source - human being - builing envelope" on the basis of the energy and exergy approaches. This model takes into account signals from the skin and the core, and exergy is calculated on the basis of the ambient temperature, which ensures correct integration of the human exergy flows when the entire system is considered.

2. The designed model allowed calculating the minimum human body exergy consumption and the appropriate room air temperature at different values of the mean radiant temperature and the outside air temperature equal to $273 \mathrm{~K}$. It is found that the Predicted Mean Vote (PMV) index of human thermal sensation under these conditions and at the minimum human body exergy consumption is between -0.34 and -0.42 .

3. We have compared the dependence of comfortable air temperature on the mean radiant temperature for different models of thermal comfort. These parameters are important in the comprehensive analysis and design of the system "heat source - human being - building envelope". The comfortable indoor air temperature is the initial value in the design and exploitation of a heat source, whereas the mean radiant temperature allows taking into account the effect of building envelopes. We have calculated the standard deviation $\mathrm{S}$ from the comfortable room air temperature at different values of the mean radiant temperature in comparison with the model where PMV=0. In Bogoslovsky's model, $\mathrm{S}=5.1{ }^{\circ} \mathrm{C}$ and $5.7^{\circ} \mathrm{C}$; this model allows taking into account the intensity of human activity, so it is recommended when this factor is most important. In the designed model, $\mathrm{S}$ is the lowest and equals to $1.4{ }^{\circ} \mathrm{C}$; therefore, using this approach can reduce the room air temperature by $1.4^{\circ} \mathrm{C}$. The application of the designed model of comfortable room conditions is scientifically justified on the basis of the second law of thermodynamics and can reduce energy consumption due to decreasing the room air temperature.

\section{References}

1. Katic, K. Thermophysiological models: a first comparison [Text] / K. Katic, V. Zeiler, G. Boxem // First German - Austrian IBPSA Conference (RWTH Aechen University), 2014. - P. 595-602.

2. Gagge, A. P. A standart predictive index of human response to the thermal enviroment [Text] / A. P. Gagge, A. P. Fobelets, L. G. Berglund. // ASRAE Transactions. - 1971. - Vol. 77. - P. 247-262.

3. Fanger, P. O. Assessment of man's thermal comfort in practice [Text] / P. O. Fanger // Occupational and Environmental Medicine. 1973. - Vol. 30. - P. 313-324. doi: 10.1136/oem.30.4.313

4. Bogoslovskij, V. N. Otoplenie [Text] / V. N. Bogoslovskij, A. N. Skanavi. - Moscow: Strojizdat, 1991. - 735 p.

5. Tabunshhikov, A. Yu. Energoeffektivnye zdaniya i innovacionnye inzhenernye sistemy [Text] / A. Yu. Tabunshhikov //Ventilyaciya, otoplenie, kondicionirovanie vozduha, teplosnabzhenie i stroitel'naya teplofizika. - 2014. - Vol. 1. - P. 6-11.

6. Chupryna, H. M. Integrovana edyna energetychna model' budivli [Text] / H. M. Chupryna // Upravlinnya rozvytkom skladnyh systemy. - 2014. - Vol. 17. - P. 125-131.

7. Nikitin, E. E. Optimizaciya vybora energoeffektivnyh proektov modernizacii sistem teplosnabzheniya v usloviyah finansovyh ogranichenij [Text] / E. E. Nikitin // Problemi zagal'noi energetiki. - 2011. - Vol. 3. - P. 25-31.

8. Malyns'ka, L. V. Optymizaciya rozpodilu investycijnogo kapitalu za energoefektyvnymy komponentamy [Text] / L. V. Malyns'ka, S. M. Malyns'kyj // Ekonomika i region. - 2012. - Vol. 4 (35). - P. 172-178.

9. Ratushnyak, G. S. Upravlinnya proektamy energozberezhennya shlyahom termorenovacii' budivel' [Text]: navch. pos. / G. S. Ratushnyak, O. G. Ratushnyak. - Vinnycya: VNTU, 2006. - 106 p.

10. Schmidt, D. Low Exergy Systems for High-Performance Buildings, Communities [Text] / D. Schmidt // Energy and Buildings. 2009. - Vol. 41, Issue 3. - P. 331-336. doi: 10.1016/j.enbuild.2008.10.005

11. Açıkkalp, E. Advanced low exergy (ADLOWEX) modeling and analysis of a building from the primary energy transformation to the environment [Text] / E. Açıkkalp, C. Yucer, A. Hepbasli, T. Karakoc // Energy and Buildings. - 2014. - Vol. 81. - P. 281-286. doi: 10.1016/j.enbuild.2014.06.024 
12. Investigation of effective parameters on the human body exergy and energy model [Electronic resource] // 7-th International Exergy, Energy and Enviroment Symposium, 2015. - Available at: http://www.researchgate.net/publication/278018763

13. Deshko, V. I. Ekonomichno docil'nyj teplovyj zahyst budivli z riznymy dzherelamy teploty [Text] / V. I. Deshko, N. A. Buyak // Naukovi visti Nacional'nogo tehnichnogo universytetu Ukrai'ny “Kyi'vs'kyj politehnichnyj instytut. - 2009. - Vol. 3. - P. 14-20.

14. Deshko, V. I. Vybir teplovogo zahystu ta dzherela tepla iz vrahuvannyam komfortnyh umov u budivli [Text] / V. I. Deshko, N. A. Buyak, I. Yu. Bilous // Visnyk KNTUTD. - 2015. - Vol. 5, Issue 90. - P. 71-80.

15. Zolfagari, A. A new simplified model for evaluating non-uniform thermal sensation caused by wearing clothing [Text] / A. Zolfagari, M. Maererfat // Building and Environment. - 2010. - Vol. 45, Issue 3. - P. 776-783. doi: 10.1016/j.buildenv.2009.08.015

16. Tokunaga, K. Human-body exergy balance calculation under un-steady state conditions [Text] / K. Tokunaga, M. Shukuya // Building and Environment. - 2011. - Vol. 46, Issue 11. - P. 2220-2229. doi: 10.1016/j.buildenv.2011.04.036

17. Dovyak, M. Connective thinking of building envelope - Human body exergy analysis [Text] / M. Dovyak, M. Shukuya, A. Krainer // International Journal of Heat and Mass transfer. - 2015. - Vol. 90 - P. 1015-1025. doi: 10.1016/j.ijheatmasstransfer.2015.07.021

18. Caliskan, H. Energetic and exergetic comparation of the human body for summer season [Text] / H. Caliskan // Energy conversion and management. - 2013. - Vol. 76. - P. 169-176. doi: 10.1016/j.enconman.2013.07.045

19. Simone, A. A relation between calculated human body exergy consumption rate and subjectively assessed thermal sensation [Text] / A. Simone, J. Kolarik, T. Iwamatsu, H. Asada, M. Dovyak, L. Schellen et al. // Energy and Buildings. - 2011. - Vol. 43, Issue 1. P. 1-9. doi: 10.1016/j.enbuild.2010.08.007

20. Shukuya, M. Human body exergy balance and thermal comfort [Text] / M. Shukuya, M. Saito, K. Isawa et al. // Working Repoprt of IEA ECBS Annex 49, Low exergy systems for high performance building and communities, 2010.

21. Prek, M. Thermodunamic analysis of human heat and mass transfer and their impact on thermal comfort [Text] / M. Prek // International journal of heat and mass transfer. - 2005. - Vol.48, Issue 3-4. - P.731-739. doi: 10.1016/j.ijheatmasstransfer.2004.09.006

22. Gagge, A. P. An effective temperature scale based on a simple model of human physiological regulatory response [Text] / A. P. Gagge, J. A. Stolwilk, Y. Nishi // ASRAE Transactions. - 1971. - Vol. 77. - P. 247-262. 